\title{
Introducing High School Students to Engineering Fundamentals by Four Weeks Engineering Innovation Summer Program
}

Pawan Tyagi and Christine Newman ${ }^{\mathrm{b}}$

${ }^{a}$ Mechanical Engineering, University of the District of Columbia, Washington DC-20008

${ }^{\mathrm{b}}$ Center of Educational Outreach, Johns Hopkins University, Baltimore MD 21218

\begin{abstract}
Preparing high school students for engineering disciplines is crucial for the sustainable scientific and technological developments in the USA. This paper discusses a precollege program, which not only expose students to various engineering disciplines but also enable them to consider engineering as the profession. The four-week long "Engineering Innovation (EI)" course is offered every year to high school students by the center of outreach, Johns Hopkins University. EI program is designed to develop problem-solving skills through extensive hands on engineering experiments. A team consisting of an instructor, generally a PhD in Engineering, and a teaching fellow, generally a high school science teacher, closely work with students to pedagogically inculcate basics of core engineering disciplines such as civil, mechanical, electrical, materials, and chemical engineering. EI values independent problem-solving skills and simultaneously promote the team spirit among students. A number of crucial engineering aspects such as professional ethics, communications, technical writing, and understanding of common engineering principles are inculcated among high school students via well-designed individual and group activities. This paper discusses the model of EI program and its impact on students learning and their preparation for the engineering career.
\end{abstract}

Keywords: education; University of the District of Columbia; engineering education; summer program

1. Introduction: Shortage of engineering students threatens US's role as world's leading innovator. ${ }^{1}$ According to CNN news unprepared college students entering in science, engineering, and mathematics drop out after the first year itself; the alarming percentage of dropout is around 20\%. ${ }^{2}$ Engineering workforce in American Industries and the 
development of cutting-edge scientific development will need an unprecedented number of engineers in near future.1 To produce a large number of highly skilled engineering graduates it is crucial to make the high school students interested and prepared in engineering disciplines. ${ }^{1,3}$ Early exposure of engineering disciplines provides unique opportunity for the high school students to evaluate engineering profession as a future career. ${ }^{4}$ In addition to early engineering exposure, a more useful aspect of attending an introductory engineering program may be to earn transferable college credits. Transferable college credits have two utilities: (a) make the college education affordable, and (b) reduce the course load in the initial years and allow student to settle in college with a convenient pace.5, At present there are a large number of introductory engineering programs, however rarely these program are ABET accredited and provide transferable college credits to high school students. On the other hand there a vast number of courses at community colleges and universities which allow high school students to earn college, credits by attending specific courses; however, such courses are not specifically designed for high school students. Moreover, such courses are unable to give fundamental understanding about engineering disciplines to high school students via rigorous experimental approaches or hands on experience.

Introductory engineering programs for the high school students vary dramatically in their content and nature of instructions. Some of the popular engineering introduction programs are iD Tech camps, NASA SHARP program, National Youth Science Camp, Student Materials Camp, introduction to engineering program at University of Notre Dame etc. Most of the existing programs, which serve as the bridge between high school and college program in engineering, have following shortcomings.

(1) Highly specific to an engineering topic, or too generic to give critical level of understanding about engineering basics.

(2) Less emphasis on engineering fundamentals, more emphasis on demonstrations

(3) Instructors are generally skilled in one engineering branch and do not have sufficiently clear understanding about other engineering disciplines, to incite genuine interest in other areas. For instance an instructor with electrical engineering background is highly unlikely to teach the concepts of civil engineering. 
To overcome above stated shortcomings Center of Outreach, Johns Hopkins University conducts Engineering Innovation (EI) program for the high school students. ${ }^{7}$ EI is a four weeks long summer program that exposes high school students to major engineering disciplines like mechanical, civil, chemical, electrical, and materials. EI is a compact version of EN.500.110 What is Engineering? Course designed by Dr. Michal Karweit for the students with undecided major at JHU. This paper discusses the EI program and its salient features in preparing high school students for engineering profession.

\section{Introduction of EI program: EI} program benefits high school

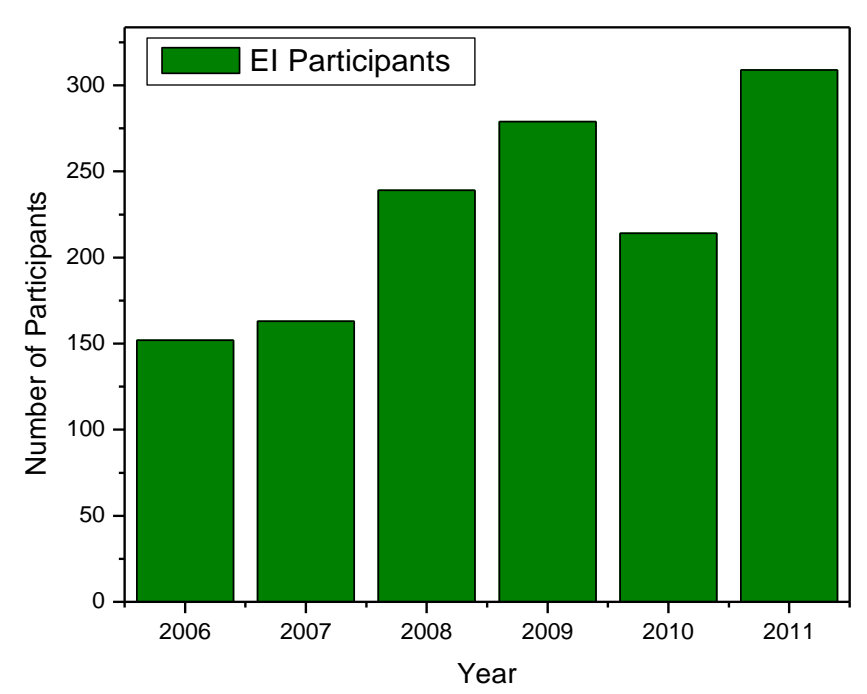

Fig. 1: Number of participants in EI program conducted from 2006-2011.

students in three main areas: (a) introduce them to various engineering areas while improving their STEM skills and self-efficacy, ${ }^{8}(\mathrm{~b})$ provide transferrable college credits ${ }^{5}$ to eligible students, and (c) mitigate the disconnect between college and high school education. ${ }^{9} \mathrm{EI}$ is becoming popular and every year increasing number of participants is joining this program, not only from the USA but also from the abroad. In 2011, 309 high school students attended EI program at various sites in the USA (Fig. 1).

During 2011, following 16 sections were taught in three states (Maryland, Pennsylvania, and California) and the District of Columbia:

- California Lutheran University located in Thousand Oaks, California

- California State University, Fullerton (CSU Fullerton) located in Fullerton, California

- Eastern Technical High School located in Baltimore, Maryland

- Johns Hopkins University, Elkridge campus (JHU Elkridge) located in Elkridge, Maryland

- Johns Hopkins University, Homewood Campus (JHU Homewood) located in Baltimore, Maryland (four sections - A, B, C, and D)

- Johns Hopkins University, Rockville campus (JHU Rockville) located in 
Rockville, Maryland (two sections - A and B)

- Tuscarora High School located in Frederick, Maryland (two sections - A and B).

- Pasadena City College located in Pasadena, California

- Sci-Tech High School (Sci-Tech) located in Harrisburg, Pennsylvania.

- University of Baltimore (UB), located in Baltimore, Maryland

- University of the District of Columbia (UDC) located in the District of Columbia.

For every site, an instructor, generally with a $\mathrm{PhD}$ degree in an engineering discipline, and a regional high school teacher, generally with several year of teaching experience, are paired to conduct EI program. Before the beginning of actual EI program instructors and teaching fellows undergo one week rigorous training at Johns Hopkins University campus. During training instructors and teaching fellows are trained in teaching fundamentals of multiple engineering disciplines. During training instructors and teaching fellows are supervised to conduct a variety of engineering experiments which high school students will be required to do under the EI program for their problem based learning. ${ }^{10}$

EI course include the lecture and experiments pertaining to a number of important engineering disciplines. ${ }^{7}$ In order to connect the class room instructions and the experimental learning to the real life applications students are asked to apply learned material to make functional engineering systems. The engineering systems, that student produce are designed to emphasize the core concepts of specific engineering streams.

To teach the components of mechanical, materials and civil engineering EI students make bridges. The bridge is expected to be made up of various trusses. Students are taught civil and mechanical engineering fundamentals to design trusses. Trusses are made up of various types of spaghettis; a cheap material which shows student that this edible stuff is can be a resource for learning engineering. Spaghettis are the structural material for the truss hence they are extensively studied under the materials experimental lab. In materials lab, students measure bending, tension, buckling properties of the various spaghettis. After understanding the various types of strengths students design individual bridge segments and justify their dimensions. Materials lab is one of the major components of the EI program, and serves multiple purposes. For instance student learn how to analyze a large set of data using Excel, do error analysis and more importantly develop a representative mathematical model from the experimental data. Developing 
the representative mathematical model from the raw experimental data teaches student how to approach a new and vaguely defined real life problem. Such skills are the core strengths of an engineer or scientist which is generally never taught by a formal course. A student learn them as the need arise and that to in varying degree; as a major drawback such skills are not discussed in general context and their connection to science and engineering problems pertaining to real life situations remain incompletely explored. EI endowed high school with the ability to deal with new technological problems via simple yet well designed hands on experiments.

EI program acknowledge the fact that most of the high school participants did not preparatory courses to assimilate engineering concepts. To bridge the knowledge gap and to provide an inquiry base teaching of engineering fundamentals generally EI instructor present interactive lectures on the major topics. For instance before the materials lab a class room discussion is presented about the materials properties, usage, and testing. In order use a material as structural material students are taught statistics. Students are asked to apply their understanding about statistics in virtual experiments. In virtual bridge designer experiment students design their bridge and analyze nature of compressive or tensile loads on the individual components of a bridge. After selecting a bridge design, based on their understanding of statistics, student construct individual trusses/ bridge components utilizing their knowledge about spaghettis' tensile, buckling and bending strength learnt from the materials class and lab.

To further teach the civil engineering basics or at least a small component of it students perform remote measurement lab. This lab utilizes meter scale and string as the surveying tools to measure the aerial distance between the apexes of two multistory buildings. This outdoor lab teaches the ways to estimate engineering quantities using limited resources. Students apply trigonometry to accomplish the assignment and apply calculus for determining the systematic and random type common errors in their measurements. This EI assignment also let student experience the utility of learning math and their applicability in engineering and science.

To teach the electrical engineering concepts students are engaged in developing mechatronics system, which is a light sensing robotic car. Students are taught about the procedure to develop microcontrollers performing the intended tasks. To guide the students through the complex concepts, students are taught about the logic circuit and how to develop it by using Boolean logic and logic gates (mainly NAND gate). This lab 
also enables the students to understand the basics of robotics and associated challenges. Developing a logic circuit from scratch and then seeing it functioning successfully is one of the most positive experiences that students had from the EI program.

To teach the chemical engineering basics students first attend class discussion on important chemical engineering processes like the chemical separations, chemical reactions, diffusion, chemical reactor design, and concepts of mass and energy conservations. Then students take part in chemical processes lab to experience important chemical engineering steps. Chemical separation is the main theme of chemical lab. Students do ethanol distillation from the mixture of water and ethanol. Students also do chromatography based chemical separation. Students discover how to use hydrometer, Maccabe Thiele diagram for quantifying the distillation efficiency.

EI recognize that successful and meaningful engineering career involve understanding of various other subjects, not just mastering technical skills. Other subjects, which EI also include in its curriculum, are professional ethics, finance, communication, and ability to estimate.

To teach the vital role of ethics in engineering and science an interactive session is designed. Different EI instructors conduct ethical education session in several ways; generally by presenting numerous past ethical cases which adversely impacted economy, safety, and social wellbeing. Ethical education is imparted through the discussion on the variety of case studies or hypothetical situations. Students provide their stand with regards to individual case studies. Through the discussion with peers and instructors they realize in many cases difference between right and wrong approach is not obvious. Interestingly, in the beginning EI student appeared to consider ethical discussion unnecessary or not important as they seemed to be content with their own ways of justifying right and wrong practice.

This program includes discussion and assignments on the role of money and finance in engineering. Students perform calculations to understand how the value of money changes with time. How a long term project may be impacted by changing value of money and availability of finance? EI lesson focuses on inculcating the importance of time and money in engineering. EI students are exposed to several types of interest rates, inflation, and method of justifying long term finance via various strategies. 
Engineering disciplines are heavily based on communications. In engineering, it is crucial that one engineer effectively communicate the guideline and instruction for the other engineers to enable the economical, safe and efficient completion of a project. For instance, design engineers must effectively communicate the design of an engineering system to the production engineers. To make high school student realize the importance of communication a number of assignment and activities are incorporated in the EI program. EI Students partake in an exercise in which they design mousetrap within the suggested constraint. Then this design is forwarded to randomly chosen students to build it just "based on written instructions". Finally during an event students test their mousetrap design and give their feedback about the issues they encountered. This is a simple yet highly efficient way to impart the importance of clear articulation and effective communication. In the second communication assignment, students are asked to propose a solution to a pressing technological issue and then market their ideas to other students via a group presentation.

To encourage students to pursue engineering career EI program conduct engineering connection day. On this special day engineers from renowned companies like Northrop Grumman, Ford, local construction companies, active research scientist and higher education specialists are invited to share their insights and experience with EI students. Engineering professional discuss their career journey, views about engineering work they are involved in, and the message for the budding engineers like EI students. Such communication enabled EI student o experience the challenges involved in transitioning from school to college/work. ${ }^{11}$ EI students do networking, and get exposed to a number of engineering internship opportunities. For some sites higher education option is also talked about. For instance this year dean of School of Engineering at UDC talked about potential advantages of higher education and numerous funding opportunities in graduate schools.

Estimation plays crucial role in engineering projects. EI students are taught that engineers and scientist generally do not have access to accurate value of all the variables, and even they may not be aware of all the variables. Ability to estimate engineering and scientific quantities with least error becomes crucial in taking important decisions. To hone the skills of estimation EI students are administered a variety of Fermi problems. In fact instructors use them as buffer activity to break the monotony of long lectures and 
other EI activities. Most of the time EI final exam for earning college credits also includes an estimation problem.

Along with the major EI activities students are taught about graphing, report preparation, error analysis, dimensional reasoning etc.

In the final week of the EI, students work on a weeklong take home exam. Based on their performance in the final exam and grades in the EI assignments which they did throughout the program decide their final grade. In the final week of EI students work in teams to produce Spaghetti Bridge using their engineering skills. On the final day of EI bridge breaking competition is organized. Students test the strength of their bridges in the presence of peers, parents, EI staff and invited guest.

3. Program Evaluation: The degree of success of EI program is accessed by multi-facet surveys. In the beginning of EI program students are asked to fill out a pre-survey to record their skill levels, attitude for engineering, and future outlook. Similar survey is administered at the end of EI program to statistically quantify the impact of EI program. In addition EI alumni were surveyed to gauge the long term impact of EI on to participating students. Survey of EI alumni was also important to map the EI effect from the new stand point. Alumni which are currently pursuing college degree have more matured and realistic outlook to reevaluate the EI effectiveness. For conducting these surveys and to evaluate the overall effectiveness of EI program an independent program evaluator was appointed. The external program evaluator also interviewed EI students and teaching staff about the various aspects of EI program. The data discussed here is mainly drawn from the surveys of EI students.

3.1 Findings: EI program was attended by students of different demography. Data suggest that percentage of female participants was 49\% in the 2006 EI program. However, in other years it was significantly lower. In 2011 EI program only $26 \%$ participants were female (Table 1). Interestingly, percentage of white students in last three years have been in the 38-49 range; in the 2011 EI program it was 47\% (Table 1). Percentage of Asian participants ranged from 13-29. Another interesting trend was observed with minority participants. In the 2006 EI it was 73\%; however, this percentage dramatically dropped to $34 \%$. Reduction in the female and minority participants also appear to be correlated with the drop in the full or partial scholarships. Percentage of partially and fully 
supported EI participants decreased from $83 \%$ to $55 \%$. It will be interesting and important to study if minority and female participation can be boosted by the financial support.

Table 1: EI Student demographic characteristics.

\begin{tabular}{|c|c|c|c|c|c|c|}
\hline Characteristics & 2011 & 2010 & 2009 & 2008 & 2007 & 2006 \\
\hline$\%$ Female & 26 & 31 & 31 & 37 & 32 & 49 \\
\hline$\%$ White & 47 & 49 & 38 & 28 & 27 & 10 \\
\hline$\%$ Asian & 21 & 29 & 25 & 22 & 13 & 14 \\
\hline \% Minority & 34 & 30 & 38 & 50 & 60 & 73 \\
\hline $\begin{array}{c}\text { \% Full or partial } \\
\text { scholarship }\end{array}$ & 55 & 47 & 54 & 66 & 72 & 83 \\
\hline
\end{tabular}

EI program contents are considerably challenging. High school students are generally selected by ensuring that they have earned reasonable proficiency in math, science, and English. Majority of the EI participants took biology, chemistry, algebra, algebra II and geometry (Table 3). The percentage of students who attended trigonometry, pre-calculus, and calculus were 69, 68, and 26, respectively. As discussed elsewhere in this paper, students who attended trigonometry and pre-calculus were found to assimilate EI material more effectively and were more likely to earn college credits. This trend is consistent with the observation about students in STEM disciplines at UDC. Students who completed pre-calculus were highly likely to complete the college degree in time.

Table 2: Percentage of 2011 EI participants taking prior science and math classes

\begin{tabular}{|c|c|}
\hline Courses & Percentage \\
\hline Biology & 86 \\
\hline Chemistry & 82 \\
\hline
\end{tabular}




\begin{tabular}{|c|c|}
\hline Physics & 53 \\
\hline Algebra & 87 \\
\hline Algebra II & 90 \\
\hline Geometry & 91 \\
\hline Trigonometry & 69 \\
\hline Pre-calculus & 68 \\
\hline Calculus & 26 \\
\hline
\end{tabular}

EI program allowed 9 to 12 grade high school students to attend the EI program. However, $10^{\text {th }}$ and $11^{\text {th }}$ grade high school students formed the major part of EI classes (Table 4). In 2011 EI program $10^{\text {th }}$ and $11^{\text {th }}$ grade students were $34 \%$ and $51 \%$ respectively. In $2011,9^{\text {th }}$ and $12^{\text {th }}$ grade students were $2 \%$ and $5 \%$, respectively.

Table 3: EI participants' high school grade

\begin{tabular}{|c|c|c|c|}
\hline Grade & 2011 & 2010 & 2009 \\
\hline$\% 9^{\text {th }}$ & 2 & 4 & 3 \\
\hline$\% 10^{\text {th }}$ & 34 & 31 & 31 \\
\hline$\% 11^{\text {th }}$ & 51 & 62 & 59 \\
\hline$\% 12^{\text {th }}$ & 5 & 2 & 6 \\
\hline
\end{tabular}

Effectiveness of EI was measured by surveying the EI participants response to specific engineering skills before and after the completion of program. Tabulated results showed that EI program significantly enhanced a number of engineering skills (Table 4). EI participants showed the highest gain in using Boolean logic (38\% increase). EI participants learned basics of Boolean logic and then developed understanding about 
various types of logic Gates (AND, OR, NOT, NAND, XOR etc.). Students performed experiments on virtual circuit builder computer program to develop circuit diagrams to control the direction of motion of a robot car. Next highest increase was the communication of engineering design ( $37 \%$ increase). During one engineering communication exercise EI students wrote instruction for another student to construct a mouse trap. Under another communication exercise students worked in group to present solution for present day engineering issues- under this exercise they first communicated with the team members and subsequently as a team they communicated with the whole class. A significant improvement was noticed in participants understanding about dimensional analysis. After attending EI program students were able to understand the essence of dimensional quantities; their ability to give example of dimension less variables improved by $36 \%$. A major gain was noted in using Microsoft Excel ${ }^{\circledR}$ software for engineering calculation and analysis (36\% increase). During in person interview a number of EI participants expressed their amazement about the capabilities of Microsoft Excel ${ }^{\circledR}$ software. During the analysis of materials lab data students utilized Microsoft Excel ${ }^{\circledR}$ software to develop model for representing bending and bucking load as a function of length and diameter of the mechanical testing samples. Students also used this software to do error analysis and engineering calculations. Table 4 enlists the percentage improvement in various engineering related skills due to the EI program.

Table 4: Percentage of students who could perform skills before and after 2011 EI program.

\begin{tabular}{|l|c|c|c|}
\hline \multicolumn{1}{|c|}{ Skill } & $\%$ pre & $\%$ post & $\begin{array}{c}\text { Change from } \\
\text { pre to past }\end{array}$ \\
\hline Use of Boolean logic & 20 & 58 & 38 \\
\hline $\begin{array}{l}\text { Write assembly instructions that } \\
\text { someone else can follow }\end{array}$ & 39 & 76 & 37 \\
\hline $\begin{array}{l}\text { Give examples of non-dimensional } \\
\text { variables }\end{array}$ & 27 & 63 & 36 \\
\hline $\begin{array}{l}\text { Use Microsoft Excel }{ }^{\circledR} \text { to solve } \\
\text { problems }\end{array}$ & 43 & 76 & 33 \\
\hline $\begin{array}{l}\text { Design and build a structure } \\
\text { without a detailed plan }\end{array}$ & 52 & 76 & 24 \\
\hline $\begin{array}{l}\text { Describe uncertainty in a set of data } \\
\text { using standard deviation }\end{array}$ & 36 & 57 & 21 \\
\hline
\end{tabular}




\begin{tabular}{|c|c|c|c|}
\hline $\begin{array}{l}\text { Apply data in scientific or } \\
\text { engineering reasoning }\end{array}$ & 55 & 77 & 22 \\
\hline $\begin{array}{l}\text { Evaluate problems you've never } \\
\text { seen before and whose answers can't } \\
\text { be found in Google }\end{array}$ & 47 & 67 & 20 \\
\hline $\begin{array}{l}\text { Work with limits that are } \\
\text { "proportional" to one another and } \\
\text { not equal to one another }\end{array}$ & 45 & 62 & 17 \\
\hline Use logarithms to analyze data & 45 & 61 & 16 \\
\hline $\begin{array}{l}\text { Describe equations using } \\
\text { dimensions and units }\end{array}$ & 61 & 76 & 15 \\
\hline $\begin{array}{l}\text { Calculate a mean, standard } \\
\text { deviation, and variance from a set of } \\
\text { data }\end{array}$ & 62 & 76 & 14 \\
\hline $\begin{array}{l}\text { Deal with measurements that } \\
\text { contain errors }\end{array}$ & 54 & 68 & 14 \\
\hline Describe the properties of a force & 50 & 64 & 14 \\
\hline $\begin{array}{l}\text { Use a table of values to estimate a } \\
\text { solution from raw data }\end{array}$ & 60 & 74 & 14 \\
\hline Work with vector quantities & 48 & 62 & 14 \\
\hline $\begin{array}{l}\text { Develop your own problems or } \\
\text { experiments to explore a concept or } \\
\text { principle }\end{array}$ & 50 & 62 & 12 \\
\hline $\begin{array}{l}\text { Simplify a complex problem into a } \\
\text { few key issues }\end{array}$ & 58 & 70 & 12 \\
\hline $\begin{array}{l}\text { Write a complex lab report that } \\
\text { includes graphs and diagrams }\end{array}$ & 59 & 71 & 12 \\
\hline $\begin{array}{l}\text { Describe the physical properties of } \\
\text { materials }\end{array}$ & 69 & 79 & 10 \\
\hline $\begin{array}{l}\text { Know when a problem isn't posed in } \\
\text { a way that you can answer it }\end{array}$ & 59 & 68 & 9 \\
\hline $\begin{array}{l}\text { Estimate answers rather than } \\
\text { calculating them }\end{array}$ & 70 & 78 & 8 \\
\hline $\begin{array}{l}\text { Make oral presentations to an } \\
\text { audience }\end{array}$ & 64 & 72 & 8 \\
\hline $\begin{array}{l}\text { Sketch or draw two-dimensional or } \\
\text { three dimensional objects }\end{array}$ & 67 & 75 & 8 \\
\hline Use math to analyze data & 74 & 80 & 6 \\
\hline
\end{tabular}




\begin{tabular}{|l|c|c|c|}
$\begin{array}{l}\text { Work with laboratory instruments } \\
\text { or tools }\end{array}$ & 78 & 84 & 6 \\
\hline $\begin{array}{l}\text { Apply trigonometry to word } \\
\text { problems }\end{array}$ & 71 & 74 & 3 \\
\hline $\begin{array}{l}\text { Identify when you don't know } \\
\text { something in a problem }\end{array}$ & 77 & 80 & 3 \\
\hline Visualize three-dimensional objects & 73 & 76 & 3 \\
\hline $\begin{array}{l}\text { Understand and solve word } \\
\text { problems }\end{array}$ & 77 & 78 & 1 \\
\hline Be a contributing team member & 85 & 83 & -2 \\
\hline
\end{tabular}

EI program also aims to provide transferable college credits to eligible participants. EI program is ABET accredited and credits earned from this course can be utilized throughout the USA universities and colleges. To earn the college credit students are required to have good standing in EI assignments and passing the final take home exam. In 2011 EI, 62\% students earned the college credit. Percentage of student earning the college credit in the 2010, 2009, 2008 were $59 \%, 65 \%$ and $58 \%$, respectively. Mean exam score for all the 2011 EI participants was 44, 50 is the cut off to earn college credit.

Female students performed quite differently as compared to male students. Significantly more male students earned college credit than female students -54 percent versus 39 percent ( $\mathrm{chi} 2=4.64, \mathrm{p}=.031$ ). The mean exam score for male students was higher than the mean exam score for female students ( $48.5 \%$ vs. $39.5 \%, F=7.04, p=.008)$.

Minority students' performance was below average. Mean exam score for minority students was 29\%; however, mean exam score for non-minority student was $54 \%$ (Table 5). As a corollary fewer minority students earned the college credits; $29 \%$ of the minority students earned college credit, while $75 \%$ of non-minority students earned the college credit. At the sites like UDC it was observed that minority students were relatively less prepared to assimilate EI course material.

Table 5: Performance of minority students in final

\begin{tabular}{|l|c|c|}
\hline & Minority & Non-minority \\
\hline Mean exam score & $29 \%$ & $54 \%$ \\
\hline Earned college credit & $25 \%$ & $75 \%$ \\
\hline
\end{tabular}


Students' performance in EI program strongly correlated with their prior math preparation. ${ }^{12-14}$ Data suggested that students with trigonometry and pre-calculus earned better exam grades and were more successful in earning college credits. Table 6 shows the mean exam scores and receipt of college credit for students who took these two courses previously as compared to those who did not attend these courses. As shown, the mean exam score for students who took a trigonometry class prior to EI was $49 \%$, compared to a mean score of $37 \%$ for students who did not take a trigonometry class $(\mathrm{F}=14.33, \mathrm{p}=.000)$. Additionally, 55\% of students who took a trigonometry class earned college credit, compared to $38 \%$ of students who had not taken a trigonometry class prior to the program (chi2=6.93, p=.008). Similar results were found for pre-calculus. Students who had taken pre-calculus had a higher mean exam score than students who did not ( $50 \%$ versus $36 \%, F=19.95, \mathrm{p}=.000$ ) and students who took pre-calculus were also more likely to have earned college credit (56\% compared to $35 \%$ of students with no precalculus experience, chi2 $=9.88, \mathrm{p}=.002$ ). Interestingly, there was no significant difference due to the other courses listed in Table 2 . Pre-calculus and trigonometry were found to produce decisive effect on the student performance.

Table 6: Exam score and college credit for students with and without prior math experience $(n=191)$

\begin{tabular}{|c|c|c|c|c|}
\hline \multirow{2}{*}{} & \multicolumn{2}{|c|}{$\begin{array}{c}\text { Student took } \\
\text { trigonometry }\end{array}$} & \multicolumn{2}{c|}{$\begin{array}{c}\text { Student took } \\
\text { pre-calculus }\end{array}$} \\
\cline { 2 - 5 } & No & Yes & No & Yes \\
\hline $\begin{array}{c}\text { Mean exam } \\
\text { score }\end{array}$ & $37 \%$ & $49 \%$ & $36 \%$ & $50 \%$ \\
\hline $\begin{array}{c}\text { Earned college } \\
\text { credit }\end{array}$ & $38 \%$ & $55 \%$ & $35 \%$ & $56 \%$ \\
\hline
\end{tabular}

In order to compare the learning experience of students who earned the college credit and who did not their skills before and after the EI program were compared (Table 7). This comparison is important in the light of findings about the students learning who attended courses at community college and local universities to earn the college credits. Finding suggested that in many cases even though a student earned college credits but in many cases no measurable difference was noticed in skills. 
Our study reflects that student who earned college credit in EI program also garnered more skills. There were two important differences in earned skills for students who earned college credit versus those who did not. First, the percentage of students who could perform these skills after the program were quite a bit higher for students who earned credit compared to students who did not. Second, the percentage improvement in skills of students was much larger among students who earned college credit than for students who did not earn college credit. For instance, skill of writing "assembly instructions that someone else can follow" improved greatly for the students who earned the college credits (Table 7). This suggests that students who did not earn credit for the course also did not develop these skills at par with the students who earned credit. This correlation between success in earning college credit and improvement in skills is logical and expected (Table7). This lower level of skill development probably explains the lower exam scores for these students and, ultimately, why these students did not earn the college credit.

Table 7: Exam score and college credit for students with and without prior math experience $(\mathrm{n}=191)$

\begin{tabular}{|l|c|c|c|c|c|c|}
\hline & \multicolumn{3}{|c|}{ Earned credit } & \multicolumn{3}{c|}{ Did not earn credit } \\
\hline Skill & $\begin{array}{c}\% \\
\text { pre }\end{array}$ & $\begin{array}{c}\% \\
\text { post }\end{array}$ & $\begin{array}{c}\text { Change } \\
\text { from pre } \\
\text { to past }\end{array}$ & $\begin{array}{c}\% \\
\text { pre }\end{array}$ & $\begin{array}{c}\% \\
\text { post }\end{array}$ & $\begin{array}{c}\text { Change } \\
\text { from pre } \\
\text { to past }\end{array}$ \\
\hline Use of Boolean logic & 70 & 89 & 19 & 52 & 62 & 10 \\
\hline $\begin{array}{l}\text { Write assembly instructions that } \\
\text { someone else can follow }\end{array}$ & 68 & 90 & 22 & 72 & 72 & 0 \\
\hline $\begin{array}{l}\text { Give examples of non-dimensional } \\
\text { variables }\end{array}$ & 68 & 89 & 21 & 55 & 67 & 12 \\
\hline Use Excel to solve problems & 31 & 73 & 42 & 11 & 46 & 35 \\
\hline $\begin{array}{l}\text { Design and build a structure without a } \\
\text { detailed plan }\end{array}$ & 53 & 75 & 22 & 41 & 50 & 9 \\
\hline $\begin{array}{l}\text { Describe uncertainty in a set of data } \\
\text { using standard deviation }\end{array}$ & 62 & 80 & 18 & 49 & 59 & 10 \\
\hline $\begin{array}{l}\text { Apply data in scientific or engineering } \\
\text { reasoning }\end{array}$ & 57 & 76 & 19 & 44 & 56 & 12 \\
\hline
\end{tabular}




\begin{tabular}{|c|c|c|c|c|c|c|}
\hline $\begin{array}{l}\text { Evaluate problems you've never seen } \\
\text { before and whose answers can't be } \\
\text { found in Google }\end{array}$ & 59 & 76 & 17 & 41 & 52 & 11 \\
\hline $\begin{array}{l}\text { Work with limits that are } \\
\text { "proportional" to one another and not } \\
\text { equal to one another }\end{array}$ & 65 & 85 & 20 & 62 & 69 & 7 \\
\hline Use logarithms to analyze data & 36 & 65 & 29 & 37 & 51 & 14 \\
\hline $\begin{array}{l}\text { Describe equations using dimensions } \\
\text { and units }\end{array}$ & 73 & 85 & 12 & 69 & 74 & 5 \\
\hline $\begin{array}{l}\text { Calculate a mean, standard deviation, } \\
\text { and variance from a set of data }\end{array}$ & 51 & 80 & 29 & 46 & 58 & 12 \\
\hline $\begin{array}{l}\text { Deal with measurements that contain } \\
\text { errors }\end{array}$ & 47 & 73 & 26 & 45 & 55 & 10 \\
\hline Describe the properties of a force & 53 & 87 & 34 & 52 & 68 & 16 \\
\hline $\begin{array}{l}\text { Use a table of values to estimate a } \\
\text { solution from raw data }\end{array}$ & 81 & 89 & 8 & 75 & 75 & 0 \\
\hline Work with vector quantities & 61 & 76 & 15 & 58 & 64 & 6 \\
\hline $\begin{array}{l}\text { Develop your own problems or } \\
\text { experiments to explore a concept or } \\
\text { principle }\end{array}$ & 50 & 78 & 28 & 51 & 49 & -2 \\
\hline $\begin{array}{l}\text { Simplify a complex problem into a } \\
\text { few key issues }\end{array}$ & 65 & 86 & 21 & 59 & 69 & 10 \\
\hline $\begin{array}{l}\text { Write a complex lab report that } \\
\text { includes graphs and diagrams }\end{array}$ & 90 & 93 & 3 & 85 & 77 & -8 \\
\hline $\begin{array}{l}\text { Describe the physical properties of } \\
\text { materials }\end{array}$ & 66 & 81 & 15 & 69 & 72 & 3 \\
\hline $\begin{array}{l}\text { Know when a problem isn't posed in a } \\
\text { way that you can answer it }\end{array}$ & 78 & 90 & 12 & 80 & 80 & 0 \\
\hline $\begin{array}{l}\text { Estimate answers rather than } \\
\text { calculating them }\end{array}$ & 62 & 80 & 18 & 67 & 67 & 0 \\
\hline $\begin{array}{l}\text { Make oral presentations to an } \\
\text { audience }\end{array}$ & 84 & 90 & 6 & 75 & 69 & -6 \\
\hline $\begin{array}{l}\text { Sketch or draw two-dimensional or } \\
\text { three dimensional objects }\end{array}$ & 81 & 87 & 6 & 65 & 65 & 0 \\
\hline Use math to analyze data & 53 & 92 & 39 & 36 & 63 & 27 \\
\hline $\begin{array}{l}\text { Work with laboratory instruments or } \\
\text { tools }\end{array}$ & 74 & 86 & 12 & 73 & 68 & -5 \\
\hline Apply trigonometry to word problems & 65 & 83 & 18 & 54 & 61 & 7 \\
\hline
\end{tabular}




\begin{tabular}{|l|c|c|c|c|c|c|}
$\begin{array}{l}\text { Identify when you don't know } \\
\text { something in a problem }\end{array}$ & 66 & 85 & 19 & 53 & 62 & 9 \\
\hline Visualize three-dimensional objects & 31 & 79 & 48 & 24 & 49 & 25 \\
\hline Understand and solve word problems & 82 & 92 & 10 & 69 & 72 & 3 \\
\hline Be a contributing team member & 64 & 92 & 28 & 51 & 64 & 13 \\
\hline
\end{tabular}

Effect of EI program on the participants' outlook about engineering career was studied. A number of questions were asked in the pre and post survey to quantify the change in student attitude about engineering. Data suggested that there was insignificant change in students perception. Students interest in engineering before and after EI program remained practically unchanged (mean pre-score 33.9 and mean post score 33.9) (Table 8). Similar observation were recorded about the other question listed in Table 8. The unchanged perception signifies that EI participants were already quite motivated to explore engineering and its relevance to societal need. In future it may be interesting to form a section of students who are disinterested in engineering and then record the change in their attitude towards engineering before and after the EI program

Table 8: Change in attitude topic area for EI participants.

\begin{tabular}{|l|c|c|c|c|}
\hline Topic area & $\begin{array}{l}\text { Number } \\
\text { of } \\
\text { students }\end{array}$ & $\begin{array}{l}\text { Mean } \\
\text { pre-score }\end{array}$ & $\begin{array}{l}\text { Mean } \\
\text { post- } \\
\text { score }\end{array}$ & Change \\
\hline Interest in engineering & 236 & 33.9 & 33.7 & -0.2 \\
\hline $\begin{array}{l}\text { Enjoyment of engineering } \\
\text { problems/community }\end{array}$ & 217 & 55.7 & 56.3 & 0.6 \\
\hline $\begin{array}{l}\text { Perception of how } \\
\text { engineering contribute to } \\
\text { society }\end{array}$ & 233 & 26.5 & 26.2 & -0.3 \\
\hline $\begin{array}{l}\text { Perception of how } \\
\text { engineering work }\end{array}$ & 233 & 18.9 & 19.4 & 0.5 \\
\hline
\end{tabular}

Finally students were asked to rate the EI program. More than $90 \%$ student rated EI program good, very good and excellent. More than $40 \%$ students rated EI program to be very good. This data signifies that EI program was a positive experience for most of the participants. According to interviews of numerous participants, EI program enabled them to appreciate the engineering from different angles, which they never imagined. It was also noticed that student tend to utilize their positive experiences in their high school 
classes. For instance, one 2010 EI participant wrote an essay during her high school class pertaining to the meaning of numbers, her new perception developed after attending the EI program. Beside this EI has produced long-term impacts on its alumni.

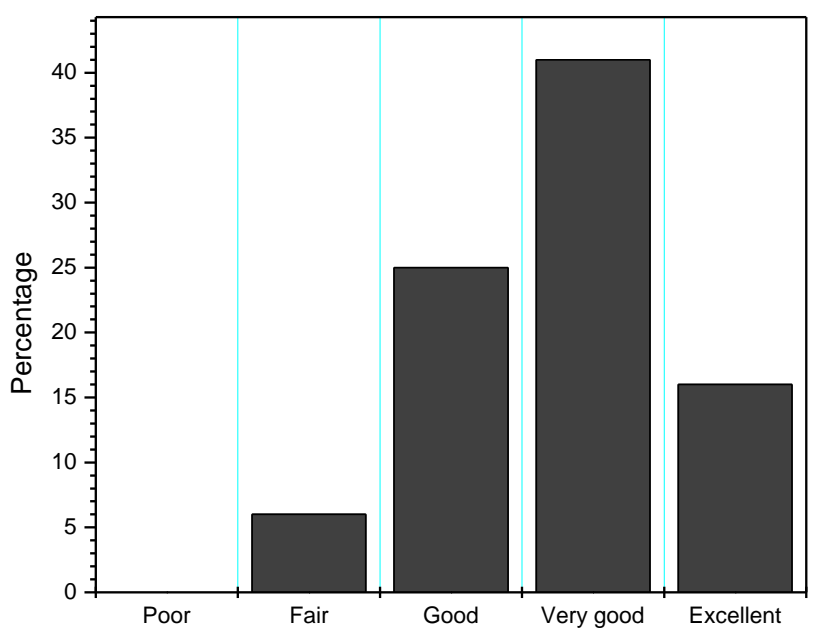

Figure 2: Student rating of 2011 EI program

To study the long-term effect of EI program alumni were asked to participate in a survey. As a positive note $46 \%$ of the alumni reported that due to EI they decided to become engineer (Table 9). Most of the EI alumni (77\%) reported that EI enabled them to think more carefully about the engineering career. Due to EI, a number of alumni realize that engineering is not the profession for them. It seems that EI is also a good medium in providing more realistic outlook about engineering for the students with different aptitudes and skill sets. It is also noteworthy that even though 2011 EI students did not showed any significant change in their aptitude about engineering (Table 8), however, once they start applying to colleges and actually begin their first year in college EI experience can assist them in making suitable choices. In future, it may be interesting to note the response of alumni about the impact of EI in their performance at college level engineering courses.

Table 9: EI influence on alumni academic and career decision $(\mathrm{n}=102)$

\begin{tabular}{|l|l|}
\hline Statement & $\begin{array}{l}\text { \% Strongly } \\
\text { agree or } \\
\text { agree }\end{array}$ \\
\hline $\begin{array}{l}\text { As a result of taking EI, I have } \\
\text { decided to become an engineer }\end{array}$ & 46 \\
\hline
\end{tabular}




\begin{tabular}{|l|c|}
$\begin{array}{l}\text { As a result of taking EI, I have } \\
\text { decided to choose another career } \\
\text { in the science }\end{array}$ & 17 \\
\hline $\begin{array}{l}\text { EI made me think more carefully } \\
\text { about whether or not engineering } \\
\text { is for me }\end{array}$ & 77 \\
\hline
\end{tabular}

The major of EI alumni was investigated. It was found that out of 102 surveyed alumni 80 alumni have made the decision about their college major. Cumulatively, 87\% EI alumni are doing major in STEM area (Table 10). Alumni who are doing college major in engineering is 56\%. This high percentage of EI alumni enrolment in STEM areas suggest that EI can play an important role in developing sustainable interest in STEM fields. This aspect is crucial because a large population of students who joined STEM area generally changed their disciplines after first year.

Table 10: College major of EI Alumni

\begin{tabular}{|l|c|}
\hline & Percent (\%) \\
\hline Engineering & 56 \\
\hline $\begin{array}{l}\text { Other } \\
\text { science/math }\end{array}$ & 11 \\
\hline $\begin{array}{l}\text { Non- } \\
\text { science/math }\end{array}$ & 1 \\
\hline Not specified & \\
\hline
\end{tabular}

Summary: Core value of EI program is that it teaches approaches to solve engineering problems and develop engineering aptitude. Students are given a number of individual and group assignments. They work in team on major engineering experiments like: materials properties, structure design, robot construction, and bridge building etc. Prior to experiments students take part in lecture and discussions on the relevant topics. Instructor and teaching fellow provide optimal pedagogy to foster independent critical thinking. During EI program students are engaged in the discussion of professional ethics, engineering economics, and data analysis. At the end of the third week students are given a take home exam. Passing in this ABET accredited EI program and satisfactory performance in EI assignments make them eligible to get three transferrable college level credits. 
Acknowledgment: PT thanks Michael Karweit for discovering engineering innovation program and nurturing it. PT also thanks Kathleen Dowell of EvalSolutions for the data analysis.

\section{References:}

1. ASEE First Bell September 2, 2011 News Letter and http://www.ajc.com/opinion/strong-u-s-needs1155439.html

2. US News Education Blog by Jason Koebler September 28 2011, http://www.usnews.com/education/blogs/high-school-notes/2011/09/28/survey-stemengagement-begins-early \& $\quad$ http://www.microsoft.com/Presspass/press/2011/sep11/0907MSSTEMSurveyPR.mspx

3. http://www.cnn.com/2011/US/05/17/education.stem.graduation/index.html

4. Mathers, N., M. Pakakis, et al. "Mars mission program for primary students: Building student and teacher skills in science, technology, engineering and mathematics." Acta Astronautica 69(7-8): 722729, and Carroll County Times, "Century senior recalls NASA summer program" Posted: Friday, September 30, 2011 5:15 am I Updated: 9:19 am, Fri Sep 30, 2011.

5. Wilbur, F. P. and D. W. Chapman (1977). "Transferability Of College Credit Earned During HighSchool." College And University 52(3): 280-287.

6. Mercurio, J. A., L. Lambert, et al. (1983). "College Credit Earned In High-School - Comparing Student Performance In Project Advance And Advanced Placement." College And University 59(1): 74-86.

7. http://engineering-innovation.jhu.edu/

8. Gore, P. A. (2006). "Academic self-efficacy as a predictor of college outcomes: Two incremental validity studies." Journal of Career Assessment 14(1): 92-115.

9. Kirst, M. W. (2004). "The high school/college disconnect." Educational Leadership 62(3): 51-55.

10. Urrestarazu, L. P., A. F. Salas, et al. "Multidisciplinary Education for New Landscape Engineering Concepts using Problem-Based Collaborative Learning. A Case Study in Spain." International Journal Of Engineering Education 27(1): 138-145.

11. Wagner, M. M. and J. Blackorby (1996). "Transition from high school to work or college: How special education students fare." Future Of Children 6(1): 103-120.

12. Hackett, G. and N. E. Betz (1989). "An Exploration Of The Mathematics Self-Efficacy." Journal For Research In Mathematics Education 20(3): 261-273.

13. Lent, R. W., F. G. Lopez, et al. (1996). "Latent structure of the sources of mathematics selfefficacy." Journal Of Vocational Behavior 49(3): 292-308.

14. Hoffman, B. "'I think I can, but I'm afraid to try": The role of self-efficacy beliefs and mathematics anxiety in mathematics problem-solving efficiency." Learning And Individual Differences 20(3): 276-283. 